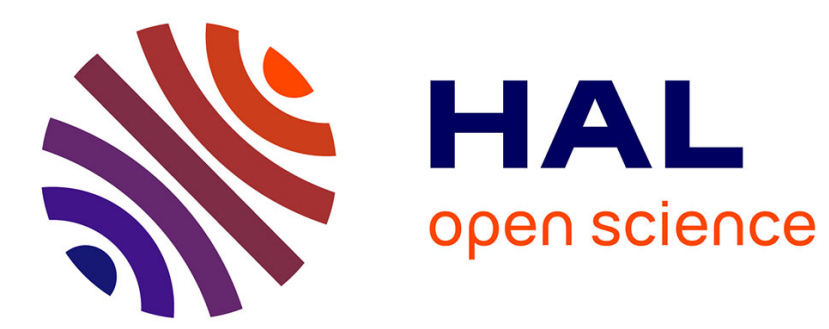

\title{
Aesthetics and randomness in cellular automata
}

\author{
Nazim Fatès
}

\section{To cite this version:}

Nazim Fatès. Aesthetics and randomness in cellular automata. Andrew Adamatzky; Genaro J. Martínez. Designing Beauty: The Art of Cellular Automata, Springer, 2016, Emergence, Complexity and Computation, 978-3-319-27269-6. 10.1007/978-3-319-27270-2_23 . hal-01256384

\section{HAL Id: hal-01256384 \\ https://inria.hal.science/hal-01256384}

Submitted on 14 Jan 2016

HAL is a multi-disciplinary open access archive for the deposit and dissemination of scientific research documents, whether they are published or not. The documents may come from teaching and research institutions in France or abroad, or from public or private research centers.
L'archive ouverte pluridisciplinaire HAL, est destinée au dépôt et à la diffusion de documents scientifiques de niveau recherche, publiés ou non, émanant des établissements d'enseignement et de recherche français ou étrangers, des laboratoires publics ou privés.

\section{(ㅇ)(1) $\$$}

Distributed under a Creative Commons Attribution - NonCommercial - NoDerivatives| 4.0 


\title{
Aesthetics and randomness in cellular automata
}

\author{
Nazim Fatès \\ Inria Nancy - Grand Est \\ 615 rue du Jardin Botanique, 54600 Villers-lès-Nancy ; France, \\ nazim.fates@inria.fr
}

January 14, 2016

We propose two images obtained with an asynchronous and a stochastic cellular automaton. Deterministic cellular automata are now well-studied models and even if there is still so much to understand, their main properties are now largely explored. By contrast, the universe of asynchronous and stochastic is mainly a terra incognita. Only a few islands of this vast continent have been discovered so far.

The two examples below present space-time diagrams of one-dimensional cellular automata with nearest-neighbour interaction. The cells are arranged in a ring, that is, the right neighbour of the rightmost cell is the leftmost cell, and vice versa; in formal words, indices are taken in $\mathbb{Z} / n \mathbb{Z}$, where $n$ is the number of cells. The space-time diagrams are obtained with the FiatLux software ${ }^{1}$. Time goes from bottom to top: the successive states of the system are stacked one on the other.

\section{References}

[1] Nazim Fatès. Remarks on the cellular automaton global synchronisation problem. In Jarkko Kari, editor, Proceedings of AUTOMATA 2015, volume 9099 of Lecture Notes in Computer Science, pages 113-126. Springer, 2015.

[2] Nazim Fatès and Michel Morvan. An experimental study of robustness to asynchronism for elementary cellular automata. Complex Systems, 16:1-27, 2005.

[3] Nazim Fatès, Michel Morvan, Nicolas Schabanel, and Eric Thierry. Fully asynchronous behavior of double-quiescent elementary cellular automata. Theoretical Computer Science, 362:1-16, 2006.

[4] Gina M.B. Oliveira, Luiz G.A. Martins, Laura B. de Carvalho, and Enrique Fynn. Some investigations about synchronization and density classification tasks in onedimensional and two-dimensional cellular automata rule spaces. Electronic Notes in Theoretical Computer Science, 252:121-142, 2009.

\footnotetext{
${ }^{1}$ http://fiatlux.loria.fr
} 




Aquatic plants: space-time diagram of the $\alpha$-asynchronous Elementary Cellular Automaton $148=$ CFG. The evolution shows a particular evolution for $n=100$ and $\alpha=0.4$. Blue and white cells represent states 1 and 0 , respectively. (c) 2015 Nazim Fatès.

An Elementary Cellular Automaton is a one-dimensional binary cellular automaton with nearest-neighbour communication between cells. One of the simplest way of making this model asynchronous is to use $\alpha$-asynchrony. With this updating scheme, a cell updates with probability $\alpha$ and keeps its state with probability $1-\alpha$.

The figure presents ECA with Wolfram's decimal code 148 ; it can alternatively be coded as rule CFG with the notation that lists the active transitions, see Ref. [3].

The behaviour of this rule is known for fully asynchronous updating [3], that is, when only cell is selected randomly at each time step, but it is an open problem to determine its properties with $\alpha$-asynchronous updating [2]. 




An art nouveau rug: space-time diagram of a stochastic CA designed for solving the global synchronisation problem. The setting is: $k=130, n=400$. Each state is associated with a colour drawn in palette arbitrarily constructed. (c) 2015 Nazim Fatès.

The global synchronisation problem consists in making a cellular automaton blink at the same pace, whatever the initial condition. Genetic algorithms provide very good solutions to this problem [4]. However, it was recently shown that obtaining an exact solution of the problem with a deterministic rule is a difficult task [1].

By contrast, the problem is very easy to solve with a stochastic rule, and for any number of states. Assume that we have $k$ states, at each time, each cell simply decides randomly and uniformly to either keep its own state or to copy the state of its left or right neighbour. Then, it updates by adding one to the state that was copied and making a modulo- $k$ operation. In formal words, the local rule reads :

$$
f(x, y, z)=(\mathcal{U}(x, y, z)+1) \bmod k,
$$

where $\mathcal{U}(x, y, z)$ selects of the three variables with uniform probability.

As shown above, starting from a random initial condition where each cells selects one of the 130 states independently and uniformly, the evolution of the rule make large portions of space synchronise progressively. Ultimately, the system should evolve to a uniform configuration and will then continue to "blink" for ever. Since the boundaries between homogeneous regions perform a non-biased random walk, the average time of synchronisation scales quadratically with the ring size $n$. It is an open problem to know if there is a rule whose average synchronisation time would scale linearły with $n[1]$. 